Article

\title{
Social Reproduction at the End of Times: Jenni Fagan's and John Burnside's Degrowth Imaginaries
}

\section{Arianna Introna}

Division of Literatures and Languages, University of Stirling, Stirling FK9 4LA, UK; arianna.introna@stir.ac.uk

Received: 15 September 2018; Accepted: 22 May 2019; Published: 28 May 2019

Abstract: This article will explore how degrowth imaginaries inform the representation of social reproduction and environmental collapse in Jenni Fagan's The Sunlight Pilgrims (2016) and John Burnside's Havergey (2017). It will argue that the two novels deploy the trope of the end of times to frame the unravelling of the world-ecology that binds capital and nature together in the Capitalocene, according to Jason Moore. They suggest that this is what makes possible, and necessary, a re-organisation of social reproduction and of the patterns of energy consumption or generation with which this is entangled. The first part of this article will examine the metabolic rift with which The Sunlight Pilgrims and Havergey are concerned, while the second part will delineate the ways in which degrowth imaginaries frame the representation of reorganised forms of social (re-)production. Drawing on disability studies and situating The Sunlight Pilgrims and Havergey within the disciplinary framework of Scottish literature, I will continue to consider how Burnside's and Fagan's novels feature narratives of disability and the nation. These may come across as marginal to the plot but function as the foci through which the politics of the degrowth communities represented come to the fore.

Keywords: Scottish literature; degrowth; petrocultures; social reproduction; disability; nation

\section{Introduction}

Set in the midst of deepening environmental crisis and in its aftermath, respectively, Jenni Fagan's The Sunlight Pilgrims (2016) and John Burnside's Havergey (2017) are concerned both with the damage inflicted on nature and society by capitalism and with attempts at organising social relations differently to survive its consequences. Havergey follows a pilot who has travelled from 2017 to 2056 Havergey, a remote island off the coast of Scotland, as he gets to know the history of the community of nomads who have made the island their home after surviving The Collapse, a period associated with waves of epidemics responsible for killing 90 percent of the world population. Set in a Scottish caravan park, The Sunlight Pilgrims recounts the story of Dylan, arrived from London after the deaths of his mother and his grandmother, and his neighbours-Constance, her eleven-year-old transgender daughter Stella, and elderly, crippled Barnacle as they navigate the beginnings of what appears to be a new Ice Age. What both novels narrate is ultimately the end of a 'capitalist world-ecology' (Moore 2016, p. 6) through the prism of both its causes and the possibilities it opens up. I will argue that, in doing so, they deploy environmental collapse as a conjuncture which frames as both necessary and possible the radical reorganisation of social reproduction in a direction reminiscent of that advocated by the degrowth movement.

The concept of social reproduction has been developed by autonomist and feminist Marxists to put centre stage in the study of capitalism the assertion that 'the reproduction of human beings is the foundation of every economic and political system' (Federici 2012, p. 2). This involves valorising the labour located 'at the heart of creating or reproducing society as a whole' (Bhattacharya 2017, p. 2) within, against, and beyond capitalism. Havergey and The Sunlight Pilgrims are concerned both with 
the crisis of social reproduction that constitutes the inevitable consequence of capitalist processes of extraction and with the reproductive work that underpins attempts at reorganising society after and during environmental collapse, respectively. For Silvia Federici, reproductive work constitutes the 'ground zero for revolutionary practice' because it is through the 'day-to-day activities by means of which we produce our existence' that we can both 'reconstruct the world as a space of nurturing, creativity, and care' (Federici 2012, p. 2). The extent to which this reconstruction is achieved in the worlds depicted by Havergey and The Sunlight Pilgrims can be tested through consideration of the narratives of energy, disability, and state responsibility for environmental disaster and its mitigation through which the imaginaries of social reproduction that inform the two texts are refracted.

Narratives of energy and narratives of disability function as prisms through which the failure of social reproduction in the Capitalocene and alternative ways of living are imagined. As I will trace in the first two sections of this article, the degrowth imaginary that informs Havergey and The Sunlight Pilgrims is sustained by a double focus on the unsustainability of social reproduction under capitalism and on the alternative ways of organising social activities, relations, and patterns of energy consumption called forth by socioenvironmental disaster. Central to this double focus is the relationship both novels establish between environmental collapse, failure of social reproduction, and issues of energy dependency. I will argue that this not only exemplifies how 'questions of energy become legible in moments of crisis' (Szeman et al. 2017, p. 5) but also prompts reflection on the literary uses afforded by the conflation of energy narratives and the trope of socioecological collapse. Graeme Macdonald suggests that literature can have a role in reproducing or resisting dominant energy cultures (Macdonald 2013); my concern will be to test the extent to which The Sunlight Pilgrims and Havergey forge a way for thinking differently, or not, our relationship with energy within the wider context of social reproduction in which it is implicated. As for narratives of disability, in Section 3 of this article I will explore how Fagan's and Burnside's degrowth imaginaries, which are also energy narratives, intersect with representations of disability. Drawing on disability studies, I will reflect on the place and role assigned to disability in the 'new forms of living and producing' (D'Alisa et al. 2015, p. 4) embraced by the communities represented. Its presence or absence in the reorganisation of social reproduction prompts us to evaluate the radical change both novels call for against the extent to which disabled people are part of, or excluded from, this change.

As for narratives of the nation, they figure in the form of critiques of the incompatibility between the function of the state to 'regulate and shape the reproduction of [its] citizens' (Roseneil et al. 2013, p. 902) and those predicated on its being 'a moment of the process of reproduction' of capitalist social relations (Clarke 1991, p. 189). In Section 4, I will interrogate the extent to which Fagan's and Burnside's degrowth imaginaries allow the possibility for the reorganisation of social reproduction to be realised within the framework of the national community, its nation-state or under the aegis of global governmental bodies. I will situate my investigation within the disciplinary context of Scottish literary studies in order to examine how this stands in relation to the contextualism of the field. Louisa Gairn argues that 'Scottish writers in particular have been sensitive to the perceived erosion of links between language, traditional culture and the natural world' under the pressure of mass consumerism, globalisation, and the threat of environmental degradation (Gairn 2008, p. 10). Somewhat differently, Burnside and Fagan attack the foundations of a capitalist ecology and their concern lies with the erosion of the metabolic relation between nature and society that develops under capitalism, on the responsibility of state power in perpetuating it, and on the moment when the forms and ends of social reproduction become unhinged from the capitalist social national state. I will reflect on the ways in which this multifaceted concern troubles both the nationalist contextualism of Scottish literary studies and the nationed framework of the field, structurally 'articulated around the signifier of the nation' (Featherstone and Karaliotas 2017, note 1). 


\section{2. 'It's All Borrowed': Metabolic Rifts and Failures of Social Reproduction at the End of Times}

The Sunlight Pilgrims and Havergey hold humanity responsible for environmental collapse: in Fagan's novel, the oil rig worker Dylan encounters on the bus as he travels to Clachan Fells exclaims 'this Ice Age is because human beings are acting like a fucking cancer on this hereof beautiful planet We're a race of zombies fucking the earth into oblivion' (Fagan 2016, Sunlight, p. 18); as for Burnside's text, the pilot remembers how in the run-up to the Collapse people's 'eyes were fixed on the shame ... the unbearable shame-of what [they] had done and were continuing to do to the land, to the oceans, to other species, to-well, everything' (Burnside 2017, Havergey, p. 27). Both novels situate environmental degradation in the specific context of the Capitalocene intended 'not just as an economic system but as a way of organizing the relations between humans and the rest of nature' (Patel and Moore 2018, p. 3). As John Bellamy Foster notes, while human societies are always 'internal to and dependent on [a] larger earthly metabolism,' a capitalist commodity economy ultimately brings on a rift in the universal metabolism of nature by subjecting the organisation of society and its relationship with nature to the laws of exchange value (Foster 2013). Havergey and The Sunlight Pilgrims are preoccupied with the cracks that under capitalism endanger the metabolism that is 'the basis of life itself' (Foster et al. 2010, p. 7). Both novels focus on the relationship between the ways in which 'the natural conditions of human development' are put under pressure by capital accumulation (Burkett 2014, p. xx), the metabolic rift this pressure opens up, and the environmental collapse which is its ultimate consequence.

The social relations revolving around the production and consumption of energy are portrayed by Havergey and The Sunlight Pilgrims as deeply tied into these processes. The two novels deploy the end of times as the prism through which to portray how 'our relation to energy [changes] over time' (Szeman et al. 2017, p. 5). In doing so, on the one hand they highlight the relationships that bind energy consumption and generation, environmental damage and the failure of social reproduction; on the other hand, they foreground the ways in which these relationships are rooted in capitalism as a 'world-ecology, joining the accumulation of capital, the pursuit of power, and the co-production of nature in dialectical unity' (Moore 2015, p. 3). Central to Havergey is the dismantling of the wind turbine that had been erected by local magnate Hugh Follansbee 'to cash in on lavish government subsidies' (Burnside 2017, Havergey, p. 159) before the Collapse. This marks the overcoming of a political moment when wind turbines had been 'made into a catch-all solution' despite 'the damage that [they] were doing to the land and birdlife' (Burnside 2017, Havergey, p. 156) because they allowed governments not to 'take any serious measures to ... balance energy generation' (Burnside 2017, Havergey, p. 160). The novel's critique is reminiscent of that voiced by degrowth thinkers who call out the ways in which 'a technical, depoliticized debate about how to best manage the environment without harming the economy or changing the current political order' (Kallis 2017, p. 16) is responsible for making the 'call for an "exit from the [capitalist] economy"' unthinkable (Kallis 2017, p. 20).

Havergey presents, as a consequence of this, environmental catastrophe in the form of the 'elimination, or a massive diminution' of the world population (Burnside 2017, Havergey, p. 27) as the only way in which the planet can recover its equilibrium after the massive resource depletion and environmental degradation caused by capitalism: 'catastrophe was the only remedy we had left. A thousand Chernobyls,' the pilot comments (Burnside 2017, Havergey, p. 152). How the novel suggests that only an exit from the Capitalocene can open up the possibility for the restoration of a healthy metabolic relation between nature and society can be gleaned from the characterisation of the mission on which the pilot is sent. Sponsored by the one percent that owned large parts of the planet before the Collapse, the pilot was supposed to travel forward 'to see what had happened weather-wise' and convey his findings back to 'an international committee of scientists, politicians and "other stakeholders" (i.e., Big Business)' who would take measures to 'protect what was left of what we had-or at least, of what the ninety-nine percent wished they had' (Burnside 2017, Havergey, p. 29). Burnside here explicitly criticises Big Business as concerned to discover to what extent 'the unbounded 
drive of capital for valorization' has already eroded 'its own material conditions' and reached the limits of nature (Saito 2017, p. 20) while refraining from changing the system itself.

In The Sunlight Pilgrims, the materiality of the metabolic rift is rendered through energy. The energy theme draws attention to how the loss of access to communication, electricity, and fuel is central to the potential failure of social reproduction. Energy narratives force us to acknowledge 'the material and immaterial infrastructures and superstructures that shape our daily lived realities and govern our choices and mobilities within existing social, economic, and political networks' (Wilson et al. 2017, p. 12) and how these impede 'our capacity to fully address environmental problems' (ibid., p. 9). Reliance on electricity to listen to or watch the news providing information about plummeting temperatures indexes our reliance on energy and its imminent unavailability. While Stella 'turns the television up and pulls a blanket around herself,' not wanting 'to add an extra log to the fire, now they are on rations,' the radio mentions 'Snowstorm Cecilia is the most deadly winter weather on record for over two hundred years' (Fagan 2016, Sunlight, p. 201); it will later announce 'The northern British Isles are mainly frozen over ... Blackouts across the grid can be seen lit up here, here and here ... thousands and thousands of people are dying due to dangerous conditions.' We will also learn that 'a man lost in the countryside drove around in his car for four days in a snowstorm and he said he couldn't get a signal anywhere and everything looked the same. He died two streets away from home' (Fagan 2016, Sunlight, p. 272). At the very end, we encounter Dylan and the other protagonists huddled together for warmth in a cottage: when Dylan asks, 'Has anyone got a phone signal?', he receives for an answer 'A small pitiful chorus of No' (Fagan 2016, Sunlight, p. 309). His thoughts first run to the need to make use of a form of fuel power alternative to electricity as he wonders 'It's ice. No electricity, but wood. They can cook with the fire?' (Fagan 2016, Sunlight, p. 309); then, he thinks of the electrical blackouts that are affecting the wider Clachan Fells community and of 'People sitting in cold houses without heating' (Fagan 2016, Sunlight, p. 310). Energy dependency is set to haunt communities even after individual deaths, as the Prologue to The Sunlight Pilgrims anticipates that 'Corpses will be found staring into a snowy maelstrom. A van will arrive, lift the frozen ones up, drive them to the city morgue - it takes two weeks to defrost a fully-grown man' (Fagan 2016, Sunlight, p. 1).

Blackouts and increased energy dependency at subzero temperatures materialise the consequences that the metabolic rift opened up by capitalist processes of accumulation has signified for human beings and natural world alike. Fagan depicts these as intimately connected: after the deaths of his mother and his grandmother, Dylan, faced with debt and unpaid bills, reflects 'It's all borrowed: bricks; bodies; breathing-it's all on loan!'. Although he is referring to the historic cinema he has inherited, his focus moves smoothly to planetary disaster. He continues: Vast amounts of fresh water are flooding into the ocean from melting polar caps ... Eighty years on the planet if you're lucky.' Situating this in the context of the Capitalocene, he notes 'Everyone has been taken hostage. Banners and big-business are tyrannical demigods. Where is the comeback? There is no comeback because they own the people who have the guns who are there to keep the people (bankers and big-business and governments) fucking safe' (Fagan 2016, Sunlight, p. 10). Extractivism and consumerism too are portrayed as intertwined through the figure of Dylan's fellow traveler: the oil rig worker recounts 'I' $m$ on the oil rigs again, six weeks on this time ... I need the money for the missus. She goes to Brussels for lipo ... lipo on the brain she has. New tits. New nose' (Fagan 2016, Sunlight, p. 20).

\section{3. 'PLANS FOR THE REVOLUTION, LA FIN DU MONDE, EN AVANÇANT': Degrowth Communities at the End of Times}

Both novels present the implosion of the Capitalocene as opening a way for building a new relationship with energy. It is through representations of the relationships that bind communities and energy consumption or production that Havergey and The Sunlight Pilgrims deploy energy as the prism that makes visible 'the material, social, and symbolic operations' of the practices it enables (Szeman and Boyer 2017, p. 4). They simultaneously trouble current ways of being 'human and to live in society' along the lines of Keynesian models of growth (Wilson et al. 2017, p. 9) and pinpoint 'the 
specificity of humanity within the web of life' (Moore 2015, p. 7). In Havergey, the accomplishment of the transition to a different world-ecology and attendant relationship with energy is rendered through the image of the disused lighthouse which The Watcher picks out as tinged with a white 'close to Chinese white with time aged into it.' He recounts 'my eye knows as the white of the lighthouse at the harbour entrance. It's never lit these days, of course; it's just there, as a presence, a piece of history' (Burnside 2017, Havergey, p. 13). This is not so much because no ship is expected to pass by, as the role of the Watcher is precisely to look for changes in the skyline, the presence of boats included. It is because on the island there is no electricity, as suggested by the ways in which it is candlelight that allows the Pilot to study in the Archive. In The Sunlight Pilgrims, it is instead the wish and need for the establishment of a novel relationship with nature and energy that focus energy narratives as the novel is punctuated by attempts by Stella and others to absorb solar energy: Stella 'focuses, trying to absorb the suns' energy deep into her cells so when they descend into the darkest winter for 200 years, in the quietest minutes, when the whole world experiences a total absence of light-she will glow, and glow, and glow' (Fagan 2016, Sunlight, p. 3). In so doing, Stella works in the tradition of the sunlight pilgrims, mentioned to her by Dylan's grandmother, who tells her 'you can drink energy from the sun, store it in your cells so you grow strong .... we should all do it. It's like a back-up store of it in your cells,' adding that 'there were sunlight pilgrims doing it all the time-it's how they get through the dark, by stashing up as much light as they can' (Fagan 2016, Sunlight, p. 144).

Both Havergey and The Sunlight Pilgrims situate the development of alternative relationships with energy as a moment of the reorganisation of society in an ecological direction. This can be read as registering with historical and present-day forms of anti-capitalist action; environmental struggles which Burkett (2014, p. xxv) sees enacted by 'working people and their communities for sustainable and fulfilling forms of human development.' In Havergey, the intertwining of ecological and anti-capitalist struggle is encapsulated in the script entitled 'PLANS FOR THE REVOLUTION, LA FIN DU MONDE, EN AVANÇANT,' discovered by the pilot in the Archive of the island. The script is framed as a conversation between a young man, a young woman, a little girl, an artist, and an elderly woman. It is accompanied by a poster carrying images of nature being allowed to grow without human intervention and the quotation 'It is only when we have renounced our preoccupation with "I", "me", "mine", that we can truly possess the world in which we live. Everything provided that we regard nothing as property' (Burnside 2017, Havergey, p. 57). To the elderly woman's declaration 'All we need to do is ... forget the consumerist trap that has you working for things you don't need' the artist responds 'We are anarchists' and 'our deepest and most lasting belief is in order-the order we find everywhere in the natural world' (Burnside 2017, Havergey, p. 59).

The imbrication between ecological and anti-capitalist consciousness in both novels provides the ground on which different forms of social reproduction and social production from those obtaining under capitalism are established. This reading is supported by Kohei Saito's insight that, because in its attempts 'to subsume nature, capital cannot help but destroy, on an expanding scale, the fundamental material conditions for free human development,' it also breeds the 'revolutionary subjectivity that consciously demands a radical transformation of the mode of production' and of 'the relationship between humans and nature so as to ensure a more sustainable social metabolism' (Saito 2017, pp. 20-21). Discussing socioeconomic relations that include but exceed the dimension of social reproduction, Michael Hardt and Antonio Negri contend that the contemporary mode of production is social 'in a double sense: on one hand, people produce ever more socially, in networks of cooperation and interaction; and, on the other, the result of production is not just commodities but social relations and ultimately society itself' (Hardt and Negri 2017, p. xv). While, under capitalism, the terrain of social production is both where 'the talents and capacities of people to organize and rule themselves are nurtured and revealed' and where 'the most severe forms of domination facing the multitude are in play' (Hardt and Negri 2017, p. xv). The more the structure of capitalism fractures, the more the latter dimension becomes absent, allowing space for the former to develop. Similar dynamics unfold in the dimension of social reproduction, constituted by 'the activities that 
sustain the life cycle' (Kallis 2017, p. 22): a wholesale reorganisation of society based on a 'refusal' of the cheapening of reproductive work demanded by capitalism (Patel and Moore, p. 31) can only happen once this work 'is not subsumed to the logic of capital accumulation, and we control the means of our reproduction' (Federici and Vishmidt 2013). This is precisely the scenario Havergey and The Sunlight Pilgrims chart through their representation of communities committed to, and faced with the necessity of, establishing a 'world-ecology in which power, wealth, and re/production are forged in conversation with needs of the web of life, and humanity's place within it' (Moore 2016, p.11), at the end of times-and the start of a new epoch.

How Fagan's and Burnside's communities organise themselves according to logics is reminiscent of the principles that underpin the degrowth movement, which seeks a move beyond not just 'capitalism, but also productivism' (Kallis 2017, p. 24). This is suggested by how productive activity on Havergey and in Clachan Fells does not respond to the imperatives of profit-making, economism, growth, and accumulation that the degrowth movement rejects (Deriu 2017). In The Sunlight Pilgrims, Constance restores furniture taken from the city dump, which we encounter in the form of 'Jagged piles of electrical goods' and a 'mound of plastic in all different colours' (Fagan 2016, Sunlight, p. 66). In Havergey, the individual that welcomes the pilot on Havergey, Ben The Watcher, embodies the possibility for occupations that fulfil a social function to be performed according to one's taste and talents outside the Capitalocene. He explains, 'I am more than usually attentive to the subtlest shifts in the landscape... This is my talent and that makes me a Watcher' (Burnside 2017, Havergey, p. 14).

The degrowth imaginary that underpins the representation of 'alternative social-ecologies' (Kallis 2017, p. 26) in Havergey and The Sunlight Pilgrims extends to the sphere of social production and reproduction. In Havergey, the focus rests on social production, rendered as inseparable from the project of preparing for Utopia that binds together the community of the nomads who have decided to make Havergey their home. The basis for this preparation is the 'Creation Myth,' constructed from the material held in the Archive. Ben The Watcher recounts 'When the first nomads came, they found The Archive - the letters, the drawings, the notebooks-and they consumed it all greedily' because they were 'full of ideas, challenges to how they intended to live in this place' (Burnside 2017, Havergey, p. 74). On the one hand, the social relations binding together the Havergey community are defined by a conscious departure from the individualistic and competitive principles that sustain capitalism. This departure is achieved through processes of commoning. Ben The Watcher explains 'it takes a really strong community not to become competitive, not to grow factions, not to allow itself to become compromised by the desire for property, especially as a population grows-and this is why I say that we can only prepare for Utopia' (Burnside 2017, Havergey, p. 100). The extent to which practices of commoning are key to the reorganisation of social reproduction against and beyond capitalism is explained by Michael Hardt and Antonio Negri's insight that 'one key struggle on the terrain of social production plays out over the uses, management, and appropriation of the common, that is, the wealth of the earth and the social wealth that we share and whose use we manage together' (Hardt and Negri 2017, p. xvi). On the other hand, the Creation Myth prescribes an ethics of remembering reminiscent of that informing a 'reparation ecology' which prompts us and to 'see anew - the lives and labours of humans and other natures in the web of life' (Patel and Moore 2018, p. 40). In The Watcher's words, 'We should always remember ... those who came before us and, in the same thought, we should remember their mistakes ... when they [forgot] how systems work. Ecosystems, drainage systems, warning systems, social systems' (Burnside 2017, Havergey, p. 13).

As for The Sunlight Pilgrims, its concern lies with social reproduction and, specifically, with the ways in which a form of "caring in common" is indispensable for confronting environmental collapse, bringing together a revalued 'reproductive economy of care, and the reclaiming of old-and the creation of new-commons' (D'Alisa et al. 2015, p. 4). In line with how for Silvia Federici there is a need for any movement or community to put 'on its agenda its own reproduction' by creating 'forms of support and ... collectively [building] forms of reproduction' (Federici 2010, p. 26), the local assembly called 'to discuss forward planning regarding sub-zero conditions in the Clachan Fells region' 
(Fagan 2016, Sunlight, p. 96) performs a "“commoning" of reproductive/care-work' (Federici 2012, p. 126): the minister explains 'Over by the Exit doors there are lists of jobs that we need volunteers for'; these include salting roads not salted by the Council, checking 'on the elderly and infirm' and clearing 'pathways and driveways for those who cannot do so for themselves.' A pad is instead provided 'for anybody who needs help of any kind' to leave detail of the assistance they need, while church and village halls are turned into spaces 'to stay or get a hot meal or warm clothes or a bath, for anyone who needs it' (Fagan 2016, Sunlight, p. 96). In ways that intimate how 'access to energy (or energy poverty as a lack thereof)' should be considered alongside other modes of social difference and inequality (Szeman et al. 2017, p. 5), the commoning of social reproduction tellingly extends to resources and energy: a generator for the community has been ordered and the town hall has been opened to offer shelter to 'anyone who cannot afford food or heating, especially the elderly and vulnerable' (Fagan 2016, Sunlight, p. 96). The futuristic scenario of The Sunlight Pilgrims thus impels us both to reflect on what is missing from social reproduction in the present and to interrogate the extent to which it is only ecological calamity that is able to force its reorganisation.

Importantly, in both Havergey and The Sunlight Pilgrims, new forms of social production and reproduction are rooted in practices that (re-)value the 'double internality' that binds society and nature together, whereby everything that is human is 'already joined with extra-human nature and the web of life: nature that includes humans' (Moore 2015, p. 5). The post-Collapse creation of community on Havergey is grounded in exploration of 'how humans-and human organisations (e.g., empires, world markets) - fit within the web of life, and vice versa' (Moore 2016, p. 5), in line with Burnside's persuasion that 'If we could become authentically wild in our way of being, then we might save ... "what's left of the planet" (by which I mean not physical fabric as much as imaginative space)' (Burnside 2011). This exploration yields the principles that are going to govern life on Havergey: first, 'a complete and unswerving trust in the natural order, and the power of the mind ... to accommodate and adapt to that order'; secondly, 'there is no human order that could be preferred to the natural order' (Burnside 2017, Havergey, p. 49); thirdly, the principle of interanimation, 'of being continuous with all other life, and even matter itself' as against the 'sense of disconnect [that seemed] to have been the norm for many in earlier times' (Burnside 2017, Havergey, p. 52). The pilot discovers that while the Capitalocene was defined by a 'repertoire of strategies that "put nature to work"' (Moore 2016, p. 5), after its collapse and 'decades of regimentation' nature was consciously allowed to take its course and the grass to grow high (Burnside 2017, Havergey, p. 73). Key to this alternative growth process was nonownership of the land, as explained by John the Gardener, whose testimony is contained in the Archive: he writes 'We are gardeners. We serve the garden. Not the master, not the estate, but the garden... The garden belongs to nobody' (Burnside 2017, Havergey, p. 128). In The Sunlight Pilgrims too, the divide nature/society appears to be invalid in proportion as environmental collapse deepens and 'the snow and the ice and the cold [start] seeping into everybody' (Fagan 2016, Sunlight, p. 160). The interconnection between nature and human beings is offered in the opening scene of the novel, as we witness human and nonhuman animals watching the parhelia-Constance, Stella, and Dylan alongside a blackbird (Fagan 2016, Sunlight, p. 2).

\section{Wrong Bodies at the End of Times: Towards Crip Degrowth Imaginaries?}

Disability is a crucial connecting feature of the degrowth imaginaries that inform Havergey and The Sunlight Pilgrims. It can be viewed as fundamental to the ecological reimagining of social reproduction in which both novels are invested and as the testing ground on which the fulfilment of the transition to the desired alternative forms of social organisation is accomplished. Narratives of illness and disability in Havergey and The Sunlight Pilgrims traverse the space of a 'new conception of wealth' which envisions 'equity and sustainability in the reproduction of life (of all life)' (Moore 2016, p. 10). A disability studies perspective interrogates the extent to which this ecological reimagining of social reproduction amounts to a process of cripping the degrowth imaginary, where the act of cripping consists in exposing how 'able-bodiedness and able-mindedness get naturalized' (McRuer 2018, p. 24), or not. It asks to what 
extent Burnside's and Fagan's novels include in the wholesale reorganisation of social production and reproduction the "collectivizing [of] the experience of illness, pain, grieving and the "care work" involved' (Federici 2012, p. 126).

In Havergey, illness is inseparable from planetary crisis: the pilot recounts how 'several waves of disease swept the globe, killing an estimated ninety per cent of the population in a period of around eight to ten years' (Burnside 2017, Havergey, p. 26). For Rod Michalko, disability 'becomes a reminder both of the fragility of the human body and of how fortunate or graced are those who are not disabled' (Michalko 2002, p. 100). So does illness in Havergey, where it functions as a memento mori for the post-Collapse community on Havergey in line with how, for Lennard Davis, disability is 'always an actively repressed memento mori of the fate of the normal body' (Davis 1995, p. 1). The pilot is informed by Ben The Watcher that he will have to remain in Quarantine, the Archive building, for an indefinite period. In the end, we will learn that this is to allow him time to study Havergey's history and decide whether he wants to remain on the island or not. However, it is in relation to the history of the epidemics that had depopulated the planet that the pilot interprets his confinement. When Ben the Watcher directs him to Quarantine, the pilot asks 'Am I being taken to some kind of prison? Or worse?' (Burnside 2017, Havergey, p. 36) and when at the end he learns that he is free to leave Quarantine, he reflects 'So, I don't have some kind of infectious disease?' (Burnside 2017, Havergey, p. 148). Moreover, illness is positioned as symbolically alien to the Havergey community as it is presented as a product of capitalism which has no place outside the Capitalocene. The pilot lays the blame for unhealthy lives at capitalism's door by pointing out that 'if you have to make an effort to stay healthy, what are you staying healthy for?' (Burnside 2017, Havergey, p. 25). From the pilot's notebook, we learn of how before the Collapse the government had introduced 'a plan to spend four billion pounds of taxpayers' money to "nudge" [people] back to a healthier lifestyle'; he recounts, 'we weren't just unhealthy in our bodies, we were sick overall. In our minds and our nerves and, dare I say it, in our souls' (Burnside 2017, Havergey, p. 24). The time pressures of the organisation of life under capitalism are responsible for making people ill and their passing is welcomed in Havergey for this reason. However, because it does not offer any place to disabled people in its ecological reimagining of social reproduction, it fails to live up to the 'crip promise' that, through a 'severely disabled perspective,' we will be able to 'comprehend disability otherwise' and, 'collectively, somehow access other worlds and futures' (McRuer 2006, p. 208). On the contrary, disability does not belong on Havergey, as encapsulated in Ben's explanation 'We don't own property individually, other than a few mementos. What we do have is our bodies, and our ability to be well' and in his friend Phil's standard greeting 'Be well' (Burnside 2017, Havergey, p. 41). If, for Burnside, 'what matters most, in town life, is access to one another through shared spaces and experiences where everyone can participate, equally, in the common weal' (Burnside 2015), the centrality of the pursuit of good health and the absence of disabled people that defines life on Havergey suggests that Burnside's imagination of alternative social relations does not involve disabled people. This ultimately prevents the degrowth imaginary that informs Havergey to fulfil the emancipatory possibility that the reconstruction of society after environmental collapse has opened up. Like the disused lighthouse at the harbour entrance, illness and disability belong within the Capitalocene of which the Havergey nomads have broken free.

On the contrary, in The Sunlight Pilgrims, disability is located at the centre of wider communities of care focused by 'wrong bodies'-from Dylan being 'basically a giant' and acknowledging 'I was born in the wrong body' (Fagan 2016, Sunlight, p. 37), to Stella transitioning from a boy to a girl in trying to 'be true to who she is' (Fagan 2016, Sunlight, p. 55)—through the character of Barnacle. Barnacle is 'bent over into a C-shape, as if he carries the whole world on his back, as if he is Atlas and he has been conned and doesn't know that if he just bends a knee and walks away the world will stay up all on its own' (Fagan 2016, Sunlight, p. 57). A special relationship with natural light defines all dimensions of Barnacle's life in ways that enshrine the need to transform the organisation of both social relations and relationships with energy if social reproduction, whether under or beyond capitalism, is going to continue. Barnacle is an astronomer whose practice of watching the sky is tailored to the shape of 
his body. We learn that in order to watch the aurora, he has at his feet 'three old rear-view mirrors, so when it hurts his neck too much to look up and out he can still see everything by looking down' (Fagan 2016, Sunlight, p. 267) and it is 'reclined in his lounger in a way that makes it easier for him to look round, his back still bent' that he witnesses 'the colours of the sky intensify like it has an energy of its own' (Fagan 2016, Sunlight, p. 267). Fittingly, his convivial life as a disabled person rotates around activities connected to watching the natural energy of the sky and he receives the assistance he needs in order to do so. He is able to join Constance, Stella, and Dylan's aurora party because Stella helps him 'climb onto the platform at the bottom of the lift' (Fagan 2016, Sunlight, p. 263). His death too is defined by his relationship with the energy of the sky as Dylan will find him frozen, 'leaning right back, so he is still in a C-shape but he is able to look up, he has gone like that-lying there watching the stars, watching night turn to morning and waiting for the sky' (Fagan 2016, Sunlight, p. 290).

\section{5. 'The Real People, that Is, Not the "Business Community"': National Degrowth Communities?}

A disability studies perspective allows us to grasp the constituency of the communities that Havergey and The Sunlight Pilgrims represent as being involved in the restructuring of social reproduction during and after environmental collapse; Scottish literary studies, instead, offer a disciplinary framework apt to interrogate the extent to which their actions are framed by institutional or national boundaries. If 'ecologically-aware criticism is a potentially liberating influence on the study of Scottish literature, placing it within a field of enquiry that is of global relevance' (Gairn 2008, p. 3), its value also derives from the questions it can raise about the disciplinary specificity of nationed fields of study such as Scottish literary studies. Situating Burnside's and Fagan's degrowth imaginaries within the framework of Scottish literature directs our attention to how their engagement with the role institutions and communities play in perpetuating or ameliorating environmental crisis relates to the nationed framework of the field and its nationalist contextualism.

The nationed dimension of the framework of Scottish literature derives from the circularity that bedevils the definition of the field, unpacked by Alex Thomson. For Thomson, 'framed in national terms, the study of literature in Scotland will always tend to become the analysis of Scottish literature, and ultimately, of what is "Scottish" about that literature' (Thomson 2007, p. 6). This, in turn, frames what Carla Sassi identifies as the 'central tension' in 'the academic as well as in the public debate over the disciplinary definition of Scottish literature between the "national" and the "post-national" paradigms' (Sassi 2014, p. 1). On the one hand is the determination to move beyond an overarching concern with national issues in politics, culture, and literature that is the legacy of the postnationalist turn in Scottish studies (Bell 2004; Schoene 2007); on the other hand, is the interest in the ways in which the unresolved constitutional status of Scotland inevitably influences literary as much as sociopolitical spaces. The latter has been lent renewed legitimacy by the involvement of writers and literary critics in the debate leading up to the 2014 referendum on Scottish independence. The failure of the 2014 referendum and the attendant transformation of devolution into Scotland's 'indefinite future' (Hames 2017, p. 22) may well have congealed Scottish studies, politics, and society in a position suspended between their postnationalist and nationalist moments; however, the enduring legacy of the referendum rests with its demonstration of how the nationed framework of Scottish literary studies may be differentially visible depending on contextual dynamics but, structurally, cannot be overcome.

Although post-indyref novels, Havergey and The Sunlight Pilgrims exceed the terms of reference of both the national and the postnational paradigms: the end of capitalism through environmental collapse with which they are concerned simultaneously warrants the imagination of community-building at the local level and a critique of governmental institutions at multiple scales. On the one hand, in neither novel is the reorganisation of social reproduction represented organised along national lines. Havergey explicitly addresses the issue through the words of Ben The Watcher, who says 'I'm not so much interested in ideas like national character, but I do believe that place, if it's looked at closely enough, can say a great deal about how people behave' (Burnside 2017, Havergey, p. 14). He explains that 'Havergey is a wonderful place, and we have a wonderful community here. It's not like the old 
days, when community was just a political word ... Everything is shared' (Burnside 2017, Havergey, p. 41). These feelings are echoed by the pilot who comments, after taking the decision to stay on Havergey, 'That day I saw the real Havergey for the first time- by which I mean, I saw the people, the community, that had come to live there' (Burnside 2017, Havergey, p. 165). He reflects on how Havergey is 'a real community' as opposed to 'a political word, as in "community values", or the community benefits tossed out like crumbs from the tables of big developers, or community service' (Burnside 2017, Havergey, p. 42). Havergey suggests that such a 'real community' is only possible in a society that exists in harmony with the natural world and safe from the extractive drive of capitalism.

On the other hand, the denunciation of governmental responsibility for the deepening of environmental collapse that both Havergey and The Sunlight Pilgrims put forward challenges the nationalist contextualism of Scottish literary studies. After the failed 1979 devolution referendum, there originated the feeling that cultural autonomy could become a 'crucial substratum' for political autonomy 'on terms shaped by artists rather than politicians'; as a result, 'it has been very difficult to locate the politics of individual Scottish writers (or their artworks) in any context separable from politicized national identity' (Hames 2012, p. 5). This connection is ruptured in Havergey and The Sunlight Pilgrims, which portray environmental collapse as unmooring the forms and ends of social reproduction from the capitalist social national state by locating these in local communities organised against and beyond global capital as much as national governments. Havergey directly critiques the Scottish government, depicted as servicing global capitalism. We learn that under 'the last Scottish government ... any landowner could erect any number of wind turbines' despite protests by 'the people of Shetland -the real people that is, not the "business community"' (Burnside 2017, Havergey, p. 158), and that the Scottish government had thrown its legal weight behind a billionaire who sought to obliterate 'people's houses and gardens and at least one site of special scientific interest to build a luxury golf course' (Burnside 2017, Havergey, p. 157).

The Sunlight Pilgrims voices a wider critique of capitalist institutions, whether national, global, or local. It denounces these as unresponsive to the human need 'not to possess more but instead to create sustainable relations of access and use for all' (Hardt and Negri 2017, p. xv) that environmental disaster exacerbates. Fagan ridicules how the Prime Minister has released a statement saying people must stop panicking, but it seems the public do not agree' (Fagan 2016, Sunlight, p. 272) while meetings at the United Nations are called to have the 'first honest ... conversation about climate change!' (Fagan 2016, Sunlight, p. 201). The novel is equally critical of parties. Stella's wish to create her own party 'to draw up a human-rights contract that says everyone on earth must agree we are here as caretakers of the planet, first and foremost' (Fagan 2016, Sunlight, p. 41) works as an indictment of the political system within which parties belong. This is defined by corruption and the failure to take action to mitigate the unfolding environmental disaster, as intimated by the contrast between the banner held by environmental activists protesting outside Westminster- 'Corporatocracy is a crime' - and the interactive map on the news showing the areas that are going to be adversely affected by environmental collapse (Fagan 2016, Sunlight, p. 27). Finally, The Sunlight Pilgrims targets the local philanthropic provision of support as exploitative through the images of local people resenting the intrusive assistance proffered by the Sisters of Beathnoch, with a young mum muttering ' $I$ 'd rather stay at home and die in front of the telly' (Fagan 2016, Sunlight, p. 96), and of IKEA offering to double 'as a place for the community to get medical aid and shelter, buy food, get heat' (Fagan 2016, Sunlight, p. 279). That the latter has more to do with profit-making than with philanthropic concerns is suggested by the novel's rendition of IKEA's own message, which connects humanitarian and consumerist tones: 'We are here to support your family through the fucking apocalypse, people - comeback here for the rest of your life to buy corner sofas and clever Scandi kitchenware; we are all the extended human race: you, me, everybody!' (Fagan 2016, Sunlight, p. 282). Both novels express skepticism about the possibility for governmental bodies, whether national, local, or international, to progress in any radical anti-capitalist and ecological direction and a conviction that 'change can only come from the grassroots' (Kallis 2017, p. 37). 


\section{Conclusions}

This article has argued that, in Havergey and The Sunlight Pilgrims, a degrowth imaginary informs the representation of how social reproduction becomes reorganised at the moment when the Capitalocene as a 'situated, capitalist world-ecology' (Moore 2016, p. 6) unravels. It has examined the ways in which this imaginary is expressed through the representation of communities departing from the modes of production, social production, and social reproduction of the Capitalocene as well as narratives of energy, disability, and the nation. As far as energy narratives are concerned, while The Sunlight Pilgrims concentrates on the connection between degrowth transition, changes in energy availability, and a changed relationship with energy, in Havergey, the focus rests firmly on resistance to, and the dismantling of, capitalist structures of energy generation. Both novels use energy subplots to sharpen their socioecological critique as much as their imagining of alternative ways of living which become possible at the end of times. Narratives of disability in The Sunlight Pilgrims perform a similar function, intensifying the preoccupation with the need for an alternative organisation of social reproduction and for an alternative relationship with the natural world and energy. While these manage to crip the degrowth imaginary that The Sunlight Pilgrims evokes, the radical reorganising of human activity within the web of life delineated by Havergey is predicated on the purging of illness and disability both symbolically and literally; able-bodiedness and able-mindedness are the hallmarks of the Havergey community and what allows it to prosper in the degrowth transition it is undertaking in preparation for Utopia. Finally, I have suggested that approaching The Sunlight Pilgrims and Havergey within the framework of Scottish literature affords insights into the incompatibility between degrowth and nationalist politics. The Sunlight Pilgrims portrays national and global governmental bodies as disconnected from any effective social reproduction effort, while in Havergey the national government comes across as successfully fulfilling its role of collective capitalist servicing the needs of global capital at the expense of local communities; in both novels, a degrowth transition comes across as grounded locally and in self-organised forms of social production and reproduction.

Funding: This research received no external funding.

Acknowledgments: The author wishes to thank the editors of this special issue, Graeme Macdonald and Carla Sassi, for the helpful comments and suggestions they provided after reading the first draft of this article.

Conflicts of Interest: The author declares no conflict of interest.

\section{References}

Bhattacharya, Tithi. 2017. Introduction: Mapping Social Reproduction Theory. In Social Reproduction Theory: Remapping Class, Recentering Oppression. Edited by Tithi Bhattacharya. London: Pluto Press.

Bell, Eleanor. 2004. Questioning Scotland: Literature, Nationalism, Postmodernism. Basingstoke: Palgrave Macmillan. Burkett, Paul. 2014. Marx and Nature: A Red and Green Perspective. Chicago: Haymarket Books.

Burnside, John. 2011. Interview by Rachael Allen. Granta, August 16.

Burnside, John. 2015. Essay of the Week: Dreamscapes: Imagining the Perfect Scottish Town. The Herald. May 31. Available online: http://www.heraldscotland.com/opinion/13217829.Essay_of_the_week_Dreamscapes_ _imagining_the_perfect_Scottish_town/ (accessed on 10 October 2018).

Burnside, John. 2017. Havergey. Dorchester: Little Toller Books.

Clarke, Simon. 1991. State, Class Struggle, and the Reproduction of Capital. In The State Debate. Edited by Simon Clarke. London: Palgrave Macmillan.

D'Alisa, Macmillan, Federico Demaria, and Giorgos Kallis. 2015. Introduction: Degrowth. In Degrowth: A Vocabulary for a New Era. New York and London: Routledge.

Davis, Lennard. 1995. Enforcing Normalcy: Disability, Deafness and the Body. London and New York: Verso.

Deriu, Marco. 2017. La Decrescita come Passaggio di Civiltà. Prospettive sulla Transizione. Effimera. May 19. Available online: http://effimera.org/la-decrescita-passaggio-civilta-prospettive-sulla-transizione-marcoderiu/ (accessed on 10 October 2018). 
Fagan, Jenni. 2016. The Sunlight Pilgrims. London: William Heinemann.

Featherstone, David, and Lazaros Karaliotas. 2017. Challenging the Spatial Politics of the European Crisis: Nationed Narratives and Trans-local Solidarities in the Post-crisis Conjuncture. Cultural Studies 32: 286-307. [CrossRef]

Federici, Silvia. 2010. Precarious Labor: A Feminist Viewpoint. Variant. Available online: https://www.variant.org. uk/37_38texts/9PrecLab.html (accessed on 10 October 2018).

Federici, Silvia. 2012. Revolution at Point Zero. Oakland: PM Press.

Federici, Silvia, and Marina Vishmidt. 2013. Permanent Reproductive Crisis: An Interview with Silvia Federici. Mute. March 7. Available online: https://www.metamute.org/editorial/articles/permanent-reproductivecrisis-interview-silvia-federici (accessed on 10 October 2018).

Foster, John Bellamy. 2013. Marx and the Rift in the Universal Metabolism of Nature. The Monthly Review. December 1. Available online: https://monthlyreview.org/2013/12/01/marx-rift-universal-metabolism-nature/ (accessed on 10 October 2018).

Foster, John Bellamy, Brett Clark, and Richard York. 2010. The Ecological Rift: Capitalism's War on the Earth. New York: Monthly Review Press.

Gairn, Louisa. 2008. Ecology and Modern Scottish Literature. Edinburgh: Edinburgh University Press.

Hames, Scott. 2012. Introduction: Don't Feel Bought, You're Buying. In Unstated: Writers on Scottish Independence. Edited by Scott Hames. Edinburgh: Word Power Books.

Hames, Scott. 2017. Narrating Devolution: Politics and/as Scottish Fiction. C21 Literature: Journal of 21st-Century Writings 5. [CrossRef]

Hardt, Michael, and Antonio Negri. 2017. Assembly. Oxford: Oxford University Press.

Kallis, Giorgio. 2017. In Defense of Degrowth: Opinions and Manifestos. Brussels: Uneven Earth Press.

Macdonald, Graeme. 2013. Research Note: The Resources of Fiction. Review in Cultural Theory. August 1. Available online: http://reviewsinculture.com/2013/08/01/research-note-the-resources-of-culture/ (accessed on 10 October 2018).

McRuer, Robert. 2006. Crip Theory: Cultural Signs of Queerness and Disability. New York and London: New York University Press.

McRuer, Robert. 2018. Crip Times: Disability, Globalization, and Resistance. New York: New York University Press. Michalko, Rod. 2002. The Difference Disability Makes. Philadelphia: Temple University Press.

Moore, Jason W. 2015. Capitalism in the Web of Life: Ecology and the Accumulation of Capital. London and New York: Verso.

Moore, Jason W. 2016. Anthropocene or Capitalocene? Nature, History, and the Crisis of Capitalism. In Anthropocene or Capitalocene? Nature, History, and the Crisis of Capitalism. Edited by Jason W. Moore. Oakland: PM Press.

Patel, Raj, and Jason Moore. 2018. A History of the World in Seven Cheap Things: A Guide to Capitalism, Nature, and the Future of the Planet. London and New York: Verso.

Roseneil, Sasha, Isabel Crowhurst, Ana Cristina Santos, and Mariya Stoilova. 2013. Reproduction and citizenship/reproducing citizens: Editorial introduction' in Citizenship Studies. Citizenship Studies 17: 901-11. [CrossRef]

Saito, Kohei. 2017. Karl Marx's Ecosocialism: Capitalism, Nature, and the Unfinished Critique of Political Economy. New York: Monthly Review Press.

Sassi, Carla. 2014. Glocalising Scottish Literature: A Call for New Strategies of Reading. Supplement 1. The Bottle Imp. March. Available online: https://www.thebottleimp.org.uk/wp-content/uploads/2017/08/TBI2014Supplement-1-Glocalising-Scottish-literature-a-call-for-new-strategies-of-reading-Carla-Sassi.pdf (accessed on 10 October 2018).

Schoene, Berthold. 2007. Going Cosmopolitan: Reconstituting 'Scottishness' in Post-devolution Criticism. In The Edinburgh Companion to Contemporary Scottish Literature. Edited by Berthold Schoene. Edinburgh: Edinburgh University Press.

Szeman, Imre, and Dominic Boyer. 2017. Introduction: On the Energy Humanities. In Energy Humanities: An Anthology. Edited by Imre Szeman and Dominic Boyer. Baltimore: Johns Hopkins University Press.

Szeman, Imre, Jennifer Wenzel, and Patricia Yaeger. 2017. Introduction. In Fueling Culture: 101 Words for Energy and Environment. Edited by Imre Szeman, Jennifer Wenzel and Patricia Yaeger. New York: Fordham University Press. 
Thomson, Alex. 2007. "You Can't Get There from Here": Devolution and Scottish Literary History. International Journal of Scottish Literature. Available online: http://www.ijsl.stir.ac.uk/issue3/thomson.htm (accessed on 10 October 2018).

Wilson, Sheena, Adam Carlson, and Imre Szeman. 2017. On Petrocultures: Or, Why We Need to Understand Oil to Understand Everything Else. In Petrocultures: Oil, Politics, Culture. Edited by Sheena Wilson, Adam Carlson and Imre Szeman. London and Chicago: McGill-Queen's University Press. 